\title{
The Effect of Stand Density on the Development of Puccinia graminis f. sp. tritici in Barley
}

R. Dill-Macky, Assistant Professor, Department of Plant Pathology, University of Minnesota; and A. P. Roelfs, Research Plant Pathologist, Cereal Disease Laboratory, USDA, Agricultural Research Service, University of Minnesota, St. Paul 55108

\begin{abstract}
Dill-Macky, R., and Roelfs, A. P. 2000. The effect of stand density on the development of Puccinia graminis $\mathrm{f}$. sp. tritici in barley. Plant Dis. 84:29-34.

The progress of stem rust epidemics caused by race Pgt-QCCJ of Puccinia graminis f. sp. tritici was examined in field plots of the six-rowed barley cvs. Robust and Steptoe at four stand densities, and in short rows and hill plots. Cv. Robust carries Rpg1, which confers resistance to most races of $P$. graminis f. sp. tritici, other than Pgt-QCCJ, while cv. Steptoe lacks any reported genes for resistance to $P$. graminis f. sp. tritici. The stand-density treatments established were approximately double, the equivalent of, half of, and one quarter of the planting rate recommended for commercial barley. Stem rust caused by race Pgt-QCCJ spread more rapidly in cv. Steptoe than in cv. Robust, irrespective of the stand-density treatment. The effect of stand density on rust severity was, however, greater than the effect of cultivar. Rust severity was 18 to $36 \%$ greater in sparse stands than in dense stands of both cultivars. Reductions in kernel size were most severe in sparse stands where rust development was greatest. Knowledge that reduced stand densities may promote the development of stem rust in barley may be useful in refining procedures for screening breeding material for resistance to stem rust, and in allaying concern over the high levels of stem rust occasionally reported in lightly seeded seed increases and in commercial fields where sparse stands are encountered.
\end{abstract}

Additional keywords: Hordeum vulgare

A race (Pgt-QCCJ) of Puccinia graminis Pers.:Pers. f. sp. tritici Eriks. \& E. Henn., new to the Upper Midwest barley-growing area of the United States, was detected in 1989 (17). Race Pgt-QCCJ is thought to have originated in the Pacific Northwest (18). In 1989, severity of stem rust in southeastern North Dakota and west-central Minnesota ranged from a trace to $60 \%$, making this the most severe epidemic of stem rust in barley since $1954(22,25)$. Surveys indicate that race Pgt-QCCJ overwintered on susceptible winter wheats

Corresponding author: R. Dill-Macky

E-mail: ruthdm@puccini.crl.umn.edu

Published as paper No. 981220040 of the contribution series of the Minnesota Agricultural Experiment Station based on research conducted under Project 22-52. This project was supported in part by the American Malting Barley Association.

Names are necessary to report factually on available data; however, the USDA neither guarantees nor warrants the standard of the product, and the use of the name by the USDA implies no approval of the product to the exclusion of others that may also be suitable.

Accepted for publication 9 September 1999.

Publication no. D-1999-1022-02R

This article is in the public domain and not copyrightable. It may be freely reprinted with customary crediting of the source. The American Phytopathological Society, 2000. in Oklahoma and Kansas in 1989 to 1990 and was prevalent on wild grasses including Hordeum jubatum L. in the northern Great Plains (18). This race has since become established on barley, certain winter wheats, and grasses in this region (79,12,13,18-21).

All of the barley cultivars presently grown in the Upper Midwest possess Rpgl, which conferred resistance to the common races of $P$. graminis $\mathrm{f}$. sp. tritici prior to the appearance of race Pgt-QCCJ. Lines possessing Rpg1 are moderately susceptible to race Pgt-QCCJ $(5,18)$. In 1991 , concern over the presence of race Pgt-QCCJ was heightened when stem rust was detected at high levels in seed increases of breeding lines destined for commercial release. Race Pgt-QCCJ appeared to threaten the production of barley in years favorable for stem rust development. Research was directed toward the identification of resistance and development of resistant germ plasm. Although race Pgt-QCCJ has caused only minor losses in recent years $(12,13,18-21)$, the potential exists for a serious epidemic in years favorable for disease development if sufficient inoculum is generated in southern states.

In nurseries established to screen barley lines for resistance and in field surveys, distribution of stem rust within plots was frequently uneven and appeared to be related to the spatial distribution of plants (6; R. Dill-Macky, unpublished). Plants on the edges of larger plots, plants on the ends of short rows, and plants in thin stands were often severely infected when plants of the same genotype in the center of plots or in fields at normal densities had much less rust. The observed distribution of stem rust was not related to the appearance of late tillers, which are frequently observed to be severely infected. Field experiments were conducted in 1993 and 1994 to examine the effect of plant density on the development of $P$. graminis f. sp. tritici in barley.

\section{MATERIALS AND METHODS}

Two barley cultivars, Robust and Steptoe, were tested. Cv. Robust (PI 476976), a six-rowed malting barley, which is currently the most popular malting cultivar in the Upper Midwest, accounted for 42 to 85,38 to 56 , and 35 to $50 \%$ of the barley acreage in Minnesota, North Dakota, and South Dakota, respectively, between 1989 and 1998. Cv. Robust is reported to carry the gene Rpgl, conferring resistance to $P$. graminis f. sp. tritici (16). Cv. Steptoe (CIho 15229), a six-rowed barley developed at Washington State University, is a widely adapted feed-type cultivar that lacks any of the reported genes for resistance to $P$. graminis f. sp. tritici (14).

A single isolate of race QCCJ of $P$. graminis f. sp. tritici (23) was used. The isolate (90MN3572) was collected from a commercial field of spring barley in Roseau County, Minnesota in August 1990. The isolate was increased on cv. Baart wheat in the greenhouse (5). Urediniospores were collected, dried to $20 \%$ relative humidity, and stored in cryovials in an ultra-low temperature freezer $\left(-80^{\circ} \mathrm{C}\right)$ until needed.

Field experiments were conducted at the University of Minnesota, Agricultural Experiment Station, Rosemount, Minnesota in 1993 and 1994. The experimental design was a randomized complete block with four replicates. Planting rates were adjusted to establish plots (1993, 3.7 by 3.6 $\mathrm{m}$ and $1994,3.7$ by $1.8 \mathrm{~m}$ ) of each of the two cultivars at four stand-density treatments (Table 1). The established plant densities were approximately double, the equivalent of, half of, and one quarter of those recommended for commercial barley production in Minnesota. The standard planting rate for barley is $95 \mathrm{~kg} / \mathrm{ha}(85$ $\mathrm{lb} /$ acre), equivalent to 276 viable seeds $/ \mathrm{m}^{2}$. Seed was tested for germination prior to 
Table 1. Planting rates used to establish stand density treatments in Robust and Steptoe barley cultivars and emerged plant populations for 1993 and 1994 experiments

\begin{tabular}{|c|c|c|c|c|}
\hline \multirow[b]{2}{*}{ Cultivar } & \multirow[b]{2}{*}{ Stand density treatment } & \multirow[b]{2}{*}{ Planting rate $(\mathrm{kg} / \mathrm{ha})^{\mathrm{w}}$} & \multicolumn{2}{|c|}{ Plant population (plants/m row) } \\
\hline & & & 1993 & 1994 \\
\hline \multirow[t]{6}{*}{ Robust } & $2 \times \mathrm{RPR}^{\mathrm{x}}$ & 191 & $96.3 \pm 12.0$ & $75.0 \pm 8.6$ \\
\hline & RPR & 95 & $45.8 \pm 8.9$ & $39.6 \pm 8.2$ \\
\hline & $0.50 \times \mathrm{RPR}$ & 48 & $23.3 \pm 5.2$ & $26.6 \pm 6.0$ \\
\hline & $0.25 \times \mathrm{RPR}$ & 24 & $11.3 \pm 3.3$ & $13.0 \pm 3.0$ \\
\hline & Hills $^{\mathrm{y}}$ & $\ldots$ & $(8.8 \pm 2.1)$ & $(9.3 \pm 1.0)$ \\
\hline & Short rows $\mathrm{z}$ & 77 & & $103.9 \pm 15.8$ \\
\hline \multirow[t]{6}{*}{ Steptoe } & $2 \times \mathrm{RPR}$ & 191 & $91.0 \pm 23.9$ & $77.6 \pm 11.9$ \\
\hline & RPR & 95 & $47.0 \pm 5.1$ & $54.4 \pm 12.5$ \\
\hline & $0.5 \times \mathrm{RPR}$ & 48 & $27.5 \pm 5.3$ & $31.1 \pm 3.8$ \\
\hline & $0.25 \times \mathrm{RPR}$ & 24 & $16.8 \pm 4.4$ & $17.5 \pm 2.4$ \\
\hline & Hills & & $(8.3 \pm 1.5)$ & $(8.9 \pm 0.8)$ \\
\hline & Short rows & 77 & $\ldots$ & $91.9 \pm 9.6$ \\
\hline
\end{tabular}

$\bar{v}$ Values are means and standard deviations of four replicates with two samples per replicate except for 1993 hill plots, where means are of four individual hills not included in the plot design. Values for hill plots, indicated by parentheses, are the number of plants per hill plot.

${ }^{\text {w }}$ Planting rates were calculated assuming $100 \%$ germination and 28 seeds/g.

${ }^{x} \mathrm{RPR}=$ recommended planting rate for commercial barley, $95 \mathrm{~kg} / \mathrm{ha}(85 \mathrm{lb} / \mathrm{acre})$.

y Hill plot $=1993,15$ seeds/hill with hills planted on 46-cm grid $(16 \mathrm{~kg} / \mathrm{ha}) ; 1994,10$ seeds/hill with hills planted on $30-\mathrm{cm}$ grid ( $18 \mathrm{~kg} / \mathrm{ha})$.

${ }^{\mathrm{z}}$ Short rows $=5 \mathrm{~g}$ of seed planted in $1.5-\mathrm{m}$ rows.
A

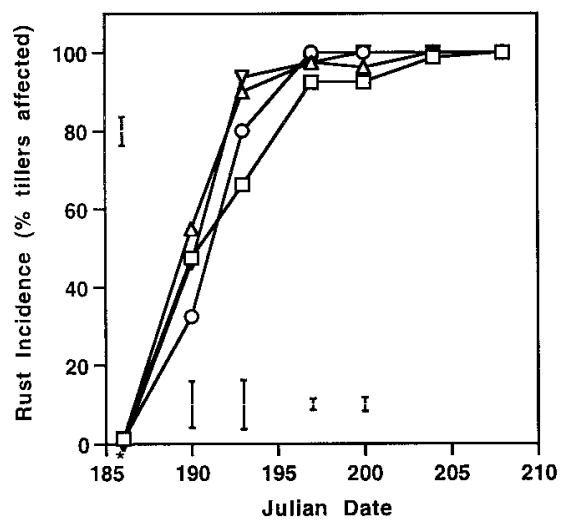

C

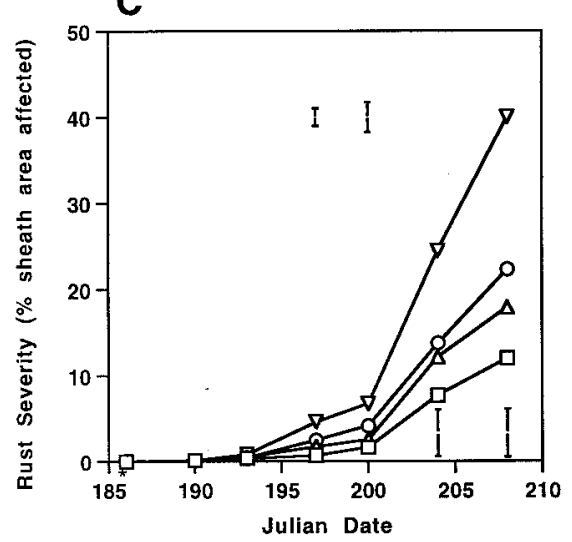

$\square$ Robust $2 x \longrightarrow$ Robust $x$
B

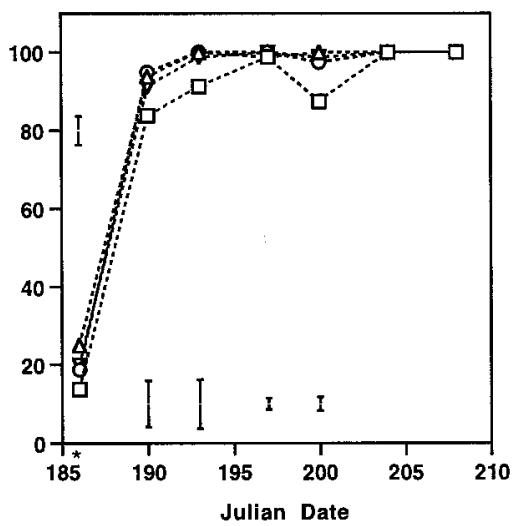

D

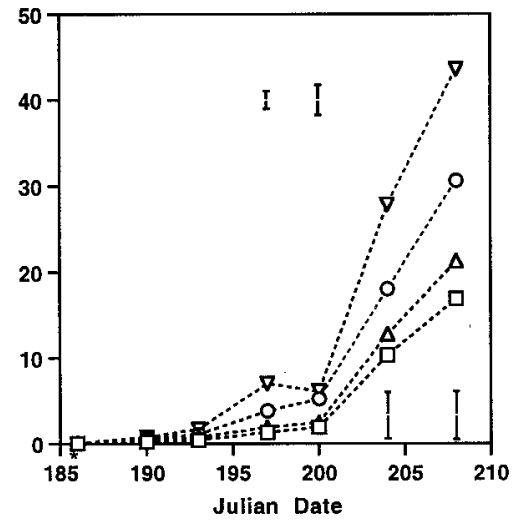

$\longrightarrow$ Robust $1 / 2 \mathrm{x} \longrightarrow$ Robust $1 / 4 \mathrm{x}$

$\cdots-\cdots \cdots$ Steptoe $1 / 2 x \quad \cdots-\nabla \cdots \cdot$ Steptoe $1 / 4 x$
Fig. 1. Development of stem rust epidemics for four stand-density treatments of Robust and Steptoe barley cultivars inoculated with race QCCJ of Puccinia graminis f. sp. tritici in 1993. Disease progress is recorded as $(\mathbf{A}, \mathbf{B})$ rust incidence (\% tillers with visible uredinia) and (C, D) rust severity (\% sheath area rusted) for $(\mathbf{A}, \mathbf{C})$ Robust and $(\mathbf{B}, \mathbf{D})$ Steptoe. Error bars indicate standard errors of means. Asterisks indicate the date of anthesis (growth stage 65) for the barley cultivars. planting. Seeding rates were adjusted to produce equivalent stand densities for the two cultivars tested. When planting rates were below the standard planting rate for barley, autoclaved grain was mixed with the plot seed to ensure a uniform distribution of live seed within the plots. Following emergence, plant populations were determined for each treatment by counting the number of seedlings in two randomly selected 1-m lengths of rows for each plot (Table 1). Plots were surrounded by a minimum distance of $1.2 \mathrm{~m}$ with barley (1993, 1:1, cvs. Robust:Excel and 1994, 5:2, cvs. Robust:M88-6), planted 21 and 27 days prior to the plots in 1993 and 1994, respectively. Cvs. Robust and Excel (PI 542047) were selected as spreaders in 1993 because they are adapted cultivars possessing Rpgl and moderately susceptible to race Pgt-QCCJ. In 1994, M88-6 was substituted for cv. Excel because this advanced breeding line from Minnesota is highly susceptible to race Pgt-QCCJ. Plots and spreaders were planted using a 10-row planter and a standard row spacing of 18 $\mathrm{cm}$. Plot rows, $3.7 \mathrm{~m}$ long, were parallel to the length of the plot. In addition to the four stand-density treatments, hill plots of cvs. Robust and Steptoe were established adjacent to the machine-planted plots in 1993. Hill plots consisted of 15 seeds hand-planted in one spot at 46-cm spacing and equidistant from spreader rows established $91 \mathrm{~cm}$ apart. In 1994, hill plots and short rows were incorporated into the trial design as additional treatments. The 1994 hill-plot treatments consisted of 25 hills centered within the plot ( 3.7 by $1.8 \mathrm{~m}$ ) in a five-by-five grid pattern. Individual hills were hand planted and consisted of 10 seeds planted in one spot. Hills were spaced at $30-\mathrm{cm}$ centers within the grid. Short rows, $1.5 \mathrm{~m}$ long, were planted with a Planet Junior hand planter. A total of 10 short rows were planted in each plot space and arranged as two columns of five rows, with rows parallel to the long side of the plot space. Rows within columns were spaced $30 \mathrm{~cm}$ from each other and the surrounding spreader rows and the columns were spaced $20 \mathrm{~cm}$ from each other and the surrounding spreader rows. Short-row and hill plots were of interest because both plot types are commonly used in rust nurseries for screening breeding material.

Spreader plants surrounding the plots were inoculated with race $P g t$-QCCJ of $P$. graminis f. sp. tritici on 17,20 , and 25 June in 1993, and 19, 22, 24, and 30 June in 1994. The majority of plants in the spreaders had flag leaves and sheaths emerging (Zadoks growth stage [GS] 37 to $41 ; 27)$ and plants within the plots were tillering (GS 21 to 22). Urediniospore suspensions of approximately 0.7 and $0.9 \mathrm{~g}$ of viable urediniospores/1.0 liter of light mineral oil (Soltrol 170, Phillips Petroleum Co., Bartlesville, OK) were applied to spreaders in 1993 and 1994, respectively. 
Inoculum was distributed using a backpack sprayer at approximately $4 \mathrm{ml} / \mathrm{m}^{2}$.

Broadleaf weeds and grasses were controlled by a single application of bromoxynil (585 g a.i./ha) and (4-chloro-2 methylphenoxy) acetic acid (805 g a.i./ha) on 11 June 1993. In 1994, a single application of bromoxynil (585 $\mathrm{g}$ a.i./ha) and diclofop-methyl (532 g a.i./ha) applied on 20 June was used to control weeds. Hand weeding at regular intervals supplemented chemical weed control in both years.

Rust development was assessed seven times, at 3- to 4-day intervals, after the initial appearance of symptoms in the plots. A total of 20 randomly selected primary tillers from each plot were assessed visually to determine the incidence and severity of rust. In 1993, tillers in hill plots generally numbered fewer than 20 ; therefore, 10 tillers per plot were assessed. Rust severity was assessed for each tiller using the key of James (11) to estimate the percentage of sheath area rusted. Rust inci-

A
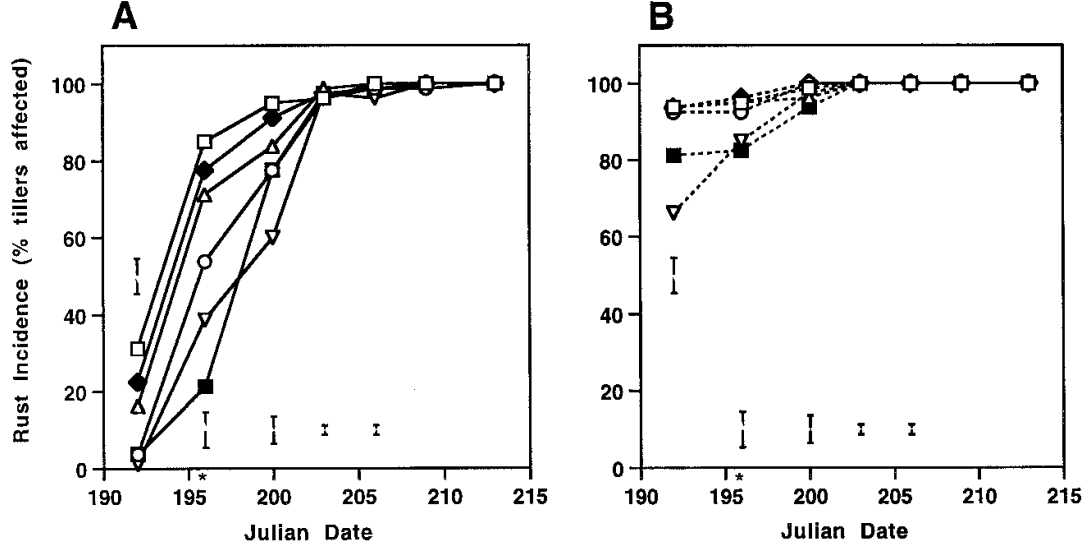

C

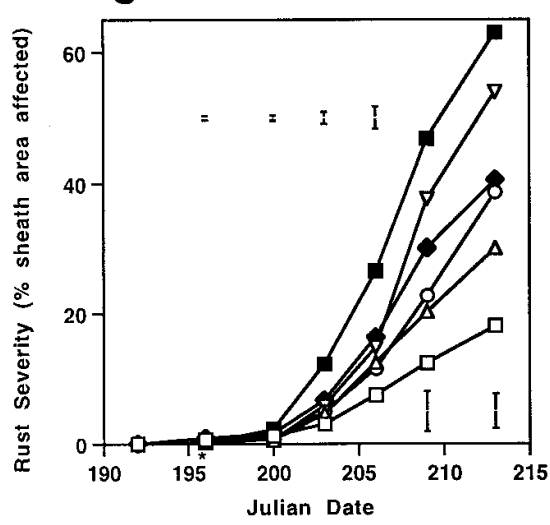

D
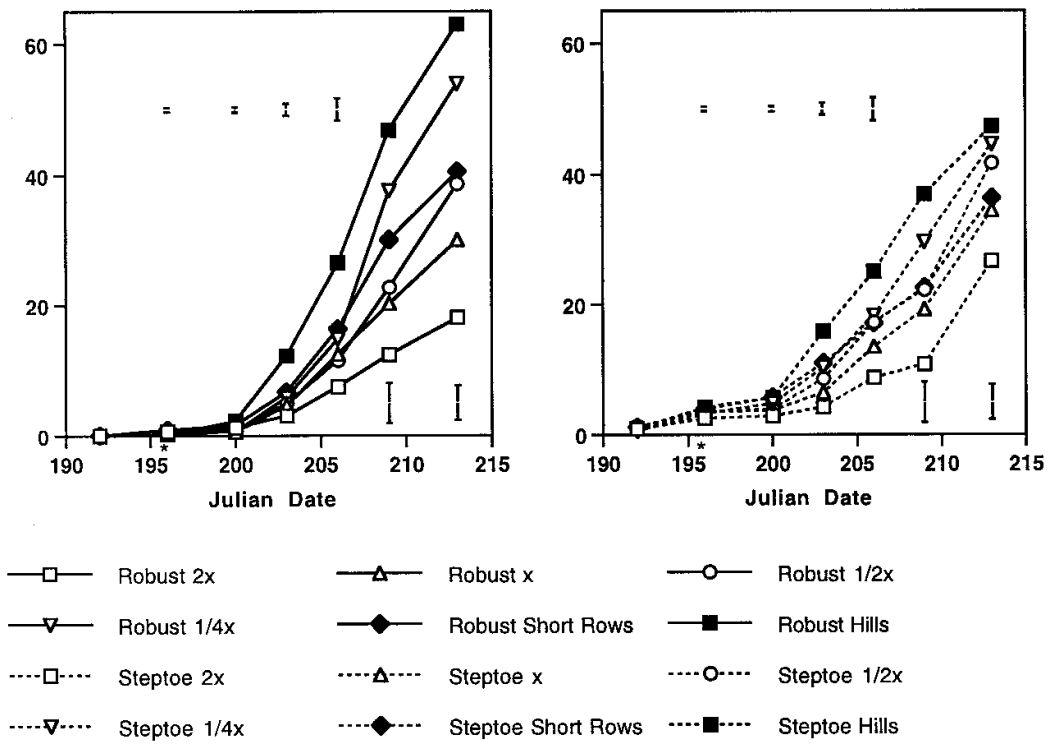

Fig. 2. Development of stem rust epidemics for six stand-density treatments of Robust and Steptoe barley cultivars inoculated with race QCCJ of Puccinia graminis f. sp. tritici in 1994. Disease progress is recorded as $(\mathbf{A}, \mathbf{B})$ rust incidence (\% tillers with visible uredinia) and $(\mathbf{C}, \mathbf{D})$ rust severity (\% sheath area rusted) for $(\mathbf{A}, \mathbf{C})$ Robust and(B, D) Steptoe. Error bars indicate standard errors of means. Asterisks indicate the date of anthesis (growth stage 65) for the barley cultivars. vested from hill plots in 1993 was insufficient to assess kernel size distribution.

Analysis of variance (ANOVA; SAS Institute, Cary, NC) for rust incidence, rust severity, hundred-head weight, TKW, and kernel size distribution was performed to test for cultivar, stand density, and interactions among the main effects for individual years. The 1993 hill-plot treatments, which were not included in the experimental design, were not included in the analysis. Where the $F$ ratio was significant $(P<$ $0.05)$, differences among treatment means were determined using least significant differences. Regression of rust incidence on stand density was performed on the data from the assessment date in each year for which the range in treatment means was the greatest (Julian day 190, 1993 and Julian day 192, 1994). Regression of rust severity on stand density was performed on the data from the final assessment (Julian day 208, 1993 and Julian day 213, 1994).

\section{RESULTS}

A total of 30 rust samples were arbitrarily collected throughout the field site in 1993 and 1994 and were tested to determine if contamination of the epidemic by other races had occurred. Race identification confirmed the presence of race PgtQCCJ from over $80 \%$ of the collections in each year of the study.

Significant differences in the incidence of stem rust were evident among treatments at the initial assessments in 1993 and 1994 (Figs. 1 and 2). Rust incidence increased rapidly, exceeding $50 \%$ by the third assessment of all treatments in both years. At final assessment, uredinia were evident on all tillers examined in both years. Rust incidence at early assessments was greater in plots of cv. Steptoe than cv. Robust, irrespective of the stand-density treatment (Figs. 1 and 2), and cultivar effects were evident in the first four assessments in each year of the study. The effect of stand density within a cultivar was generally not significant at $P \leq 0.05$ in 1993 . In 1994, a higher incidence of rust was observed in treatments with higher stand density within a cultivar at the first three assessments, although the differences between these treatments in cv. Steptoe were generally not significant. Differences in rust incidence were not evident after 19 July 1993 (Julian day 200) and 22 July 1994 (Julian day 203), by which time rust incidence exceeded $90 \%$ in all treatments for that year (Figs. 1 and 2).

Significant differences in rust severity also were evident among treatments in the 1993 and 1994 experiments (Figs. 1 and 2). ANOVA indicated that stand density treatment effects were significant $(P=0.05)$ at all assessments except the first two assessments in 1994. Cultivar treatment effects, while not significant at several of the later assessments in 1994, were otherwise significant $(P=0.05)$. The interactions of 
cultivar and stand-density treatments were generally not significant $(P=0.05)$. In 1993, rust developed most rapidly in standdensity treatments with lower stand densities. Although not included in the trial
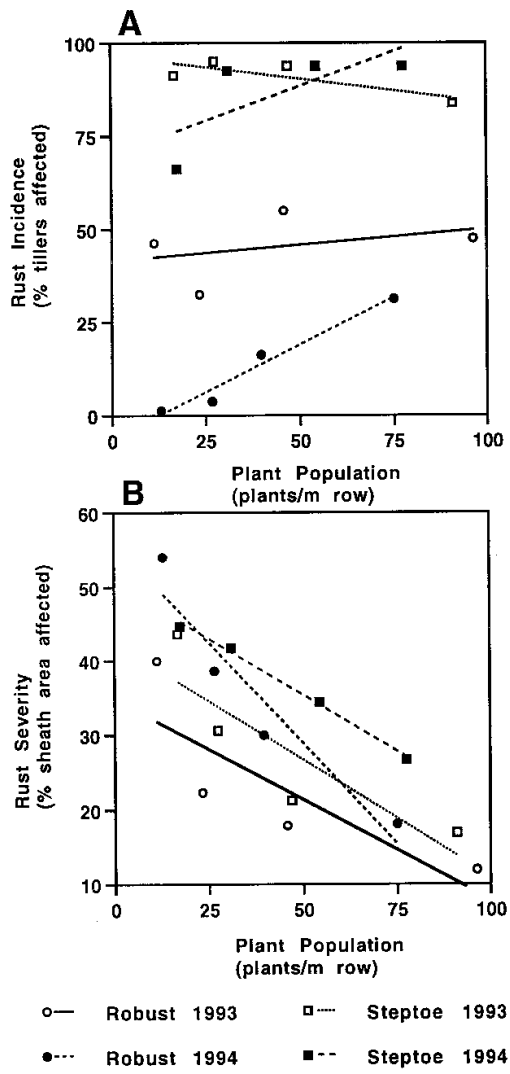

Fig. 3. Relationship between (A) stem rust incidence (\% tillers affected) and (B) severity (\% sheath area affected) and plant density (plants/m row) for Robust and Stander barley cultivars inoculated with race QCCJ of Puccinia graminis f. sp. tritici in 1993 and 1994. Stem-rust incidence values used are those from the assessment date in each year for which the range in treatment means was the greatest (Julian day 190, 1993 and Julian day 192, 1994). Stem-rust severity values used are those from the final assessment in each year (Julian day 208, 1993 and Julian day 213, 1994). design, rust severities in the hill plots were observed to be high, with rust severities of 55 and $57 \%$ for cvs. Robust and Stander, respectively, at the time of the final assessment in 1993. In 1994, rust development was highest in hill plots and treatments with low stand density, and lowest in treatments with high stand density (Fig. 2). Regression analysis indicates a poor correlation of the incidence of stem rust (GS 73 to 75 in 1993 and GS 49 to 57 in 1994) with stand density, while indicating a negative correlation between increasing plant populations and rust severity at the final assessment (GS 87 to 90), independent of the resistance genes of these two cultivars (Fig. 3).

Cv. Steptoe was observed to develop a little more rapidly than cv. Robust, with head emergence completed 2 to 3 days ahead of Robust in plots at equivalent stand density treatments. Plants of both cultivars in treatments with lower stand density generally developed more slowly than plants in treatments with higher stand density. The differences in maturity were most evident during dough development in cv. Robust treatments in 1994, where plants in the treatments with lowest stand density reached hard-dough stage (GS 87) up to 5 days after plants in the treatment with highest stand density.

Hundred-head weight measurements of cvs. Robust and Steptoe were affected by the stand-density treatments established. Losses were evident in treatments where thin stands were established and were greatest in the hill plot treatments in 1994. There were no significant differences in hundred-head weight of treatments representative of commercial planting rates (95 $\mathrm{kg} / \mathrm{ha}$ ) and the higher planting rate (191 kg/ha; Tables 2 and 3). Similarly, TKW values determined from the grain harvested in 1994 showed no increase in head weight in plots at the planting rate which exceeded the planting rate recommended for commercial fields (Tables 2 and 3). In sparse stands, where stem rust was more severe, losses of up to 61 and $40 \%$ for cvs. Robust and Steptoe, respectively, were recorded (Table 3). Losses in hundred-head weights for cv. Robust were larger in magnitude than those of cv. Steptoe, likely because Robust had a greater yield potential in the absence of rust (5). Reductions in head weight and kernel weight were reflected in losses in the percentages of plump kernels and, similarly, in increases in the percentage of screenings recovered from the grain samples (Tables 2, 3, and 4).

\section{DISCUSSION}

Attempts to isolate and quantify planting density as a factor in disease development are limited, although it is generally accepted that planting density affects disease development (3). Burdon and Chilvers (3) categorized the effect of plant density into direct geometrical effects on the frequency of inoculation, and indirect effects through interactions with the environment. In our study, plant density was found to significantly affect rust incidence and severity. Increasing plant populations either did not significantly effect or significantly increased the incidence of stem rust in barley plots, while a negative correlation between increasing plant populations and rust severity was evident and independent of the resistance genes of the two cultivars tested. There are no reports of which the authors are aware that support this finding, and reports on the effect of seeding rates on other cereal pathogens are not consistent. Reports of powdery mildew epidemics being more severe in cereals planted with wider row spacing $(1,24)$ and at reduced seeding rates (1) contrast with studies indicating a positive relationship between host density and disease development $(2,10)$. Broscious et al. (1) reported that Septoria blotch severity in winter wheat was positively associated with seeding rate, and speculated that changes in microclimatic conditions resulting from increased tiller density led to such results. Pfleeger and Mundt (15) examined the severity of wheat leaf rust in plots ranging in planting density from 81 to 324 seeds $/ \mathrm{m}^{2}$ and found no

Table 2. Hundred-head weight, thousand-kernel weight (TKW), plump kernels, medium-sized kernels, and screenings for six stand-density treatments for Robust and Steptoe barley cultivars in $1994^{y}$

\begin{tabular}{|c|c|c|c|c|c|c|}
\hline Cultivar & Treatment $^{\mathrm{z}}$ & Hundred-head weight (g) & TKW (g) & Plump kernels (\%) & Medium-sized kernels (\%) & Screenings $(\%)$ \\
\hline \multirow[t]{6}{*}{ Robust } & $2 \times \mathrm{RPR}$ & $117.9 \mathrm{e}$ & $32.0 \mathrm{~g}$ & $59.9 \mathrm{~g}$ & $34.5 \mathrm{a}$ & $5.8 \mathrm{a}$ \\
\hline & RPR & $105.4 \mathrm{~d}$ & $30.1 \mathrm{fg}$ & $50.7 \mathrm{fg}$ & $39.8 \mathrm{abc}$ & $9.5 \mathrm{ab}$ \\
\hline & $0.50 \times \mathrm{RPR}$ & $96.3 \mathrm{~d}$ & $27.4 \mathrm{ef}$ & $35.1 \mathrm{de}$ & $46.2 \mathrm{bcd}$ & $18.6 \mathrm{c}$ \\
\hline & $0.25 \times \mathrm{RPR}$ & $74.0 \mathrm{c}$ & $23.6 \mathrm{bc}$ & $15.2 \mathrm{ab}$ & $46.8 \mathrm{~cd}$ & $38.0 \mathrm{e}$ \\
\hline & Hills & $45.8 \mathrm{ab}$ & $20.8 \mathrm{ab}$ & $8.7 \mathrm{a}$ & $40.7 \mathrm{abc}$ & $50.6 \mathrm{f}$ \\
\hline & Short rows & $83.9 \mathrm{c}$ & $27.0 \mathrm{def}$ & $32.1 \mathrm{de}$ & $49.0 \mathrm{~d}$ & $18.9 \mathrm{c}$ \\
\hline \multirow[t]{6}{*}{ Steptoe } & $2 \times \mathrm{RPR}$ & $53.6 \mathrm{~b}$ & $29.7 \mathrm{fg}$ & $50.0 \mathrm{fg}$ & $34.2 \mathrm{a}$ & $15.8 \mathrm{bc}$ \\
\hline & RPR & $57.1 \mathrm{~b}$ & $27.8 \mathrm{ef}$ & $39.5 \mathrm{ef}$ & $39.4 \mathrm{ab}$ & $21.1 \mathrm{c}$ \\
\hline & $0.50 \times \mathrm{RPR}$ & $53.9 \mathrm{~b}$ & $24.2 \mathrm{~cd}$ & $24.0 \mathrm{bcd}$ & $43.0 \mathrm{bcd}$ & $33.0 \mathrm{de}$ \\
\hline & $0.25 \times \mathrm{RPR}$ & $54.9 \mathrm{~b}$ & $23.7 \mathrm{bc}$ & $17.0 \mathrm{abc}$ & $45.5 \mathrm{bcd}$ & $37.5 \mathrm{de}$ \\
\hline & Hills & $36.1 \mathrm{a}$ & $20.2 \mathrm{a}$ & $9.7 \mathrm{a}$ & $39.3 \mathrm{ab}$ & $51.0 \mathrm{f}$ \\
\hline & Short rows & $52.4 \mathrm{~b}$ & 25.2 cde & 28.8 cde & $41.0 a b c$ & $30.2 \mathrm{~d}$ \\
\hline
\end{tabular}

y Values are means of four replicates. Values within a column followed by the same letter are not significantly different at $P=0.05$ using the least significant difference $t$ tests.

${ }^{\mathrm{z}} \mathrm{RPR}=$ recommended planting rate for commercial barley, $95 \mathrm{~kg} / \mathrm{ha}(85 \mathrm{lb} / \mathrm{acre})$. Hill plot $=10$ seeds/hill with hills planted on $30-\mathrm{cm}$ grid $(18 \mathrm{~kg} / \mathrm{ha})$. Short rows $=5 \mathrm{~g}$ of seed planted in $1.5-\mathrm{m}$ rows . 
significant effect of planting density on rust severity, although they did speculate that increased stand density and changes to microclimatic factors may contribute to the positive correlation between plant density and disease severity reported by others (Shitikova-Rusakova and Gassner in 4).

The high rust severities often observed in hill plots within rust-screening nurseries suggests that the spatial arrangement of plants may have a significant impact on the development of stem rust in barley. Fox (6) suggested that the level of intra-plot shading in hill plots could lead to more variable rust severity readings and suggested that competition between plants in hill plots, which is higher than in row plots, may effect rust severity readings in other ways. In Australia, the north side of hill plots and rows were often more severely rusted whereas, in the United States, stem rust was frequently observed to be heavier on the south side of plots (R. Dill-Macky, unpublished). These observations suggest an environmental effect on the host-pathogen interaction. It is clear that varying the plant number per unit area, and their relative distribution within a given area, will not only change plant density per se but will also change numerous other factors which interact with it. Tillering, plant growth rate, plant nutrient status, and plant-water relations are host factors which may be affected by host density. Similarly, the microenvironment within the canopy may be impacted by differences in air circulation, light penetration, temperature differential between day and night, relative humidity, and dew period among differing plant-density treatments. Our observations suggest that an effect may be observed that is due either directly or indirectly to light, and merits further investigation. As a result of these findings, stem-rust nurseries at the University of Minnesota are now designed to minimize the effects of plant distribution on stem-rust development. A design incorporating plots of short rows aligned eastwest, at $30 \mathrm{~cm}$ spacings, abutting spreader rows aligned north-south, has now been utilized for four seasons to facilitate the screening of breeding lines for stem rust resistance.

In the additional treatments created by the planting of short rows of cvs. Robust and Steptoe, rust severities were comparable to those observed in stand densities of $48 \mathrm{~kg} / \mathrm{ha}$, despite the plant populations being extremely high within the rows (Table 1 and Fig. 2). This finding also suggests that the spatial arrangement of plants, not only the number per unit area, impacts the development of race $P g t$-QCCJ in barley. This finding supports observations made by the authors and the observation described in a 1940 annual report by R. G. Shands (Division of Cereal Crops and Diseases, USDA and Department of Agronomy and Plant Pathology, University of Wiscon$\sin$ ), that rust development is not uniform within stands or with plants on the outside of fields; plants on the "sunny side" (south side in the Northern Hemisphere and north side in the Southern Hemisphere) of hill plots are more severely infected than plants situated within a uniform stand.
The effect of stand density on stem rust development has important implications for the barley industry. Seed increases of advanced lines for commercial release are frequently seeded at rates below that of commercial fields in order to achieve a greater volume of seed. The practice of thinly seeding stands favors the development of stem rust. Barley cv. Stander (PI 564743) is an example. The high level of stem rust in cv. Stander in 1991, when seed of this cultivar was increased, caused concern among researchers. Prior to this seed increase, cv. Stander had not appeared to be more susceptible than other Minnesota varieties, and subsequent testing has confirmed that the resistance in Stander is at least equivalent to that in cv. Robust (5). It is possible that reduced planting rates promoted the development of stem rust in the cv. Stander increases. In 1995, in the Red River Valley of Minnesota, stem rust was noted in several thinly planted fields. Interestingly, this phenomenon has not been observed in wheat and the observation of high levels of stem rust in seed increases of a wheat cultivar would almost certainly lead to the termination of the release process. Variability in the distribution of stem rust is observed in wheat; however, the

Table 4. Plump kernels, medium-sized kernels, and screenings for five stand-density treatments for Robust and Steptoe barley cultivars in $1993^{\mathrm{y}}$

\begin{tabular}{llccc}
\hline Cultivar & Treatment $^{\mathbf{z}}$ & Plump kernels (\%) & Medium-sized kernels (\%) & Screenings (\%) \\
\hline Robust & $2 \times$ RPR & $47.6 \mathrm{de}$ & $44.6 \mathrm{bc}$ & $7.8 \mathrm{a}$ \\
& RPR & $35.5 \mathrm{bc}$ & $50.9 \mathrm{~cd}$ & $13.7 \mathrm{bc}$ \\
& $0.50 \times \mathrm{RPR}$ & $21.2 \mathrm{a}$ & $55.2 \mathrm{~d}$ & $23.7 \mathrm{~d}$ \\
Steptoe & $0.25 \times \mathrm{RPR}$ & $17.5 \mathrm{a}$ & $49.5 \mathrm{~cd}$ & $33.1 \mathrm{e}$ \\
& $2 \times$ RPR & $63.5 \mathrm{f}$ & $29.7 \mathrm{a}$ & $6.9 \mathrm{a}$ \\
& RPR & $55.6 \mathrm{ef}$ & $33.9 \mathrm{a}$ & $10.6 \mathrm{ab}$ \\
& $0.50 \times \mathrm{RPR}$ & $43.3 \mathrm{~cd}$ & $41.1 \mathrm{~b}$ & $15.7 \mathrm{c}$ \\
& $0.25 \times$ RPR & $26.1 \mathrm{ab}$ & $46.7 \mathrm{bc}$ & $27.2 \mathrm{~d}$ \\
\hline
\end{tabular}

${ }_{\mathrm{y}}$ Values are means of four replicates. Values within a column followed by the same letter are not significantly different at $P=0.05$ using the least significant difference $t$ test.

${ }^{\mathrm{z}} \mathrm{RPR}=$ recommended planting rate for commercial barley, $95 \mathrm{~kg} / \mathrm{ha}(85 \mathrm{lb} / \mathrm{acre})$.

Table 3. Percent reductions in hundred-head weight (HHW) and thousand-kernel weight (TKW) and reductions in percentage plump kernels and increase in the percentage screenings for four stand density treatments for Robust and Steptoe barley cultivars in 1993 and $1994^{\mathrm{w}}$

\begin{tabular}{|c|c|c|c|c|c|c|c|}
\hline \multirow[b]{2}{*}{ Cultivar } & \multirow[b]{2}{*}{ Treatment $^{\mathrm{x}}$} & \multirow{2}{*}{$\begin{array}{c}\text { Reduction in HHW }(\%)^{y} \\
1994\end{array}$} & \multirow{2}{*}{$\begin{array}{c}\text { Reduction in TKW }(\%)^{y} \\
1994\end{array}$} & \multicolumn{2}{|c|}{ Reduction in plump kernels $(\%)^{\mathrm{z}}$} & \multicolumn{2}{|c|}{ Increase in screenings $(\%)^{\mathbf{z}}$} \\
\hline & & & & 1993 & 1994 & 1993 & 1994 \\
\hline \multirow[t]{6}{*}{ Robust } & $2 \times \mathrm{RPR}$ & 0 & 0 & 0 & 0 & 0 & 0 \\
\hline & RPR & 10.6 & $\mathrm{~ns}$ & 12.1 & 9.2 & 5.9 & 3.7 \\
\hline & $0.50 \times \mathrm{RPR}$ & 18.3 & 14.3 & 26.4 & 24.8 & 15.9 & 12.8 \\
\hline & $0.25 \times \mathrm{RPR}$ & 37.2 & 26.3 & 30.1 & 44.7 & 25.3 & 32.2 \\
\hline & Hills & 61.2 & 35.0 & $\ldots$ & 51.2 & $\ldots$ & 44.8 \\
\hline & Short rows & 28.8 & 15.6 & $\ldots$ & 27.8 & $\ldots$ & 13.1 \\
\hline \multirow{6}{*}{ Steptoe } & $2 \times \mathrm{RPR}$ & 0 & 0 & 0 & 0 & 0 & 0 \\
\hline & RPR & ns & ns & 7.9 & 10.5 & 3.7 & 5.3 \\
\hline & $0.50 \times \mathrm{RPR}$ & $\mathrm{ns}$ & 18.5 & 20.2 & 26.0 & 8.8 & 17.2 \\
\hline & $0.25 \times \mathrm{RPR}$ & $\mathrm{ns}$ & 20.2 & 37.4 & 33.0 & 20.3 & 21.7 \\
\hline & Hills & 32.6 & 32.0 & $\ldots$ & 40.3 & $\ldots$ & 35.3 \\
\hline & Short rows & ns & 15.2 & $\ldots$ & 21.1 & $\ldots$ & 14.4 \\
\hline
\end{tabular}

${ }^{\mathrm{w}} \mathrm{ns}$ indicates that the treatment mean did not differ significantly from the mean of the reference sample.

$\times \mathrm{RPR}=$ recommended planting rate for commercial barley, $95 \mathrm{~kg} / \mathrm{ha}(85 \mathrm{lb} / \mathrm{acre}) .1994$ Hill plot $=10$ seeds/hill with hills planted on $30-\mathrm{cm}$ grid $(18$ $\mathrm{kg} / \mathrm{ha}$ ). Short rows $=5 \mathrm{~g}$ of seed planted in 1.5 -m rows.

y Within a cultivar, the $2 \times \operatorname{RPR}(191 \mathrm{~kg} / \mathrm{ha})$ stand-density treatment was used as the reference sample to determine the percentage of reduction in hundredhead weight and TKW.

${ }^{\mathrm{z}}$ Within a cultivar, the $2 \times \mathrm{RPR}(191 \mathrm{~kg} / \mathrm{ha})$ stand-density treatment was used as the reference sample to determine the reduction in percentage of plump grain and increase in percentage of screenings. 
distribution of stem rust is generally related to available moisture (for example, wheat in low-lying areas may be more heavily rusted than the wheat on the crest of a hill).

Commercial barley growers sometimes encounter difficulties in stand establishment, and stresses can reduce tillering and result in sparse stands. Information on the effect of stand density on the development of stem rust is useful to producers. By adjusting planting rates or adopting cultural practices to maintain dense stands of barley, producers will reduce the potential of severe stem rust epidemics. Portions of commercial fields such as headlands, field edges, and access points are areas where soil compaction, reduced seeding and fertilization rates, and competition with weeds may result in reduced plant populations. A knowledge that stem rust may be severe in sparse stands of barley may also be important to observers scouting fields for diseases. Headlands and access points are often places where observers "scout" for disease; therefore, stem rust severities may be overestimated by looking at plants in these "thin" areas.

\section{ACKNOWLEDGMENTS}

We thank A. M. Elakkad, C. M. Schraut, J. L. Matheson, and the staff of the Rosemount Experiment Station for their valuable assistance.

\section{LITERATURE CITED}

1. Broscious, S. C., Frank, J. A., and Frederick J. R. 1985. Influence of winter wheat management practices on the severity of powdery mildew and Septoria blotch in Pennsylvania. Phytopathology 75:538-542.

2. Burdon, J. J., and Chilvers, G. A. 1976. Controlled environment experiments on epidem- ics of barley mildew in different density host stands. Oecologia (Berl.) 26:61-72.

3. Burdon, J. J., and Chilvers, G. A. 1982. Host density as a factor in plant disease. Annu. Rev. Phytopathol. 20:143-166.

4. Chester, K. S. 1946. The Nature and Prevention of the Cereal Rusts as Exemplified in the Leaf Rust of Wheat. Chronica Botanica, Waltham, MA

5. Dill-Macky, R., and Roelfs, A. P. 1998. The effect of race QCCJ of Puccinia graminis f. sp. tritici on the yield and quality in barley. Plant Dis. 82:674-678.

6. Fox, S. L. 1993. Genetics and pathology involving stem rust resistance in barley. Ph.D. thesis, University of Manitoba, Winnipeg, Canada.

7. Harder, D. E., and Dunsmore, K. M. 1990. Incidence and virulence of Puccinia graminis f. sp. tritici on wheat and barley in Canada in 1989. Can. J. Plant Pathol. 12:424-427.

8. Harder, D. E., and Dunsmore, K. M. 1991. Incidence and virulence of Puccinia graminis f. sp. tritici on wheat and barley in Canada in 1990. Can. J. Plant Pathol. 13:361-364.

9. Harder, D. E., and Dunsmore, K. M. 1993. Incidence and virulence of Puccinia graminis f. sp. tritici on wheat and barley in Canada in 1991. Can. J. Plant Pathol. 15:37-40.

10. Huntley, D. N. 1951. The ecology of Erysiphe graminis in barley. Iowa State Coll. J. Sci. 25:252-253.

11. James, W. C. 1971. An illustrated series of assessment keys for plant diseases, their preparation and usage. Can. Plant Dis. Surv. 51:39-65.

12. McVey, D. V., Long, D. L., and Roberts, J. J. 1996. Races of Puccinia graminis in the United States during 1994. Plant Dis. 80:85-89.

13. McVey, D. V., Long, D. L., and Roberts, J. J. 1996. Races of Puccinia graminis in the United States during 1995. Plant Dis. 81:306310.

14. Nilan, R. A., Morrison, K. J., and Muir, C. 1974. Steptoe barley. Wash. State Univ. Coop. Ext. Serv. Ext. Circ. 392.

15. Pfleeger, T. G., and Mundt, C. C. 1998. Wheat leaf rust severity as affected by plant density and species proportion in simple communities of wheat and wild oats. Phytopathology 88:708-714.

16. Rasmusson, D. C., and Wilcoxson, R. D. 1983. Registration of Robust barley. Crop Sci. 23:1216.

17. Roelfs, A. P., Casper, D. H., Long, D. L., and Roberts, J. J. 1991. Races of Puccinia graminis in the United States in 1989. Plant Dis. 75:1127-1130.

18. Roelfs, A. P., Long, D. L., and Roberts, J. J. 1993. Races of Puccinia graminis in the United States during 1990. Plant Dis. 77:125128.

19. Roelfs, A. P., Long, D. L., and Roberts, J. J. 1993. Races of Puccinia graminis in the United States during 1991. Plant Dis. 77:129132.

20. Roelfs, A. P., Long, D. L., and Roberts, J. J. 1993. Races of Puccinia graminis in the United States during 1992. Plant Dis. 77:1122-1125.

21. Roelfs, A. P., Long, D. L., and Roberts, J. J. 1995. Races of Puccinia graminis in the United States during 1993. Plant Dis. 79:969 972.

22. Roelfs, A. P., Long, D. L., Steffenson, B. J., Jin, Y., Hughes, M. E., and Casper, D. H 1990. Barley rusts in the United States in 1990. Barley Newsl. 34:73-76.

23. Roelfs, A. P., and Martens, J. W. 1988. An international system of nomenclature for Puc cinia graminis f. sp. tritici. Phytopathology 78:526-553.

24. Shaner, G. 1973. Evaluation of slow-mildewing resistance of Knox wheat in the field. Phytopathology 63:867-872.

25. Steffenson, B. J., Jin, Y., Fetch, T. G., and Miller J. D. 1990. Reaction of five barleys to infection by race $\mathrm{QCC}$ of Puccinia graminis $\mathrm{f}$. sp. tritici. Barley Newsl. 34:99-100.

26. Tottman, D. R., and Makepeace, R. J. 1979. An explanation of the decimal code for the growth stages of cereals, with illustrations. Ann. Appl. Biol. 93:221-234.

27. Zadoks, J. C., Chang, T. T., and Konzak, C. F. 1994. A decimal code for the growth stages of cereals. Weed Res. 14:415-421. 